\title{
U-Pb geochronology of the Grenville Orogen of Ontario and New York: constraints on ancient crustal tectonics
}

\author{
K. Mezger ${ }^{1,2}$, E.J. Essene ${ }^{1}$, B.A. van der Pluijm ${ }^{1}$, and A.N. Halliday ${ }^{1}$ \\ ${ }^{1}$ Department of Geological Sciences, 1006 C.C. Little Building, University of Michigan, Ann Arbor MI 48109-1063, USA \\ ${ }^{2}$ Max-Planck-Institut für Chemie, Saarstrasse 23, Postfach 3060, W-6500 Mainz, Germany
}

Received May 5, 1992 / Accepted November 19, 1992

\begin{abstract}
Based on lithological, structural and geophysical characteristics, the Proterozoic Grenville Orogen of southern Ontario and New York has been divided into domains that are separated from each other by ductile shear zones. In order to constrain the timing of metamorphism, $\mathrm{U}-\mathrm{Pb}$ ages were determined on metamorphic and igneous sphenes from marbles, calc-silicate gneisses, amphibolites, granitoids, skarns and pegmatites. In addition, $\mathrm{U}-\mathrm{Pb}$ ages were obtained for monazites from metapelites and for a rutile from an amphibolite. These mineral ages constrain the timing of mineral growth, the duration of metamorphism and the cooling history of the different domains that make up the southern part of the exposed Grenville Orogen. Based on the ages from metamorphic minerals, regional and contact metamorphism occurred in the following intervals:

Central Granulite Terrane:

Adirondack Highlands: $1150 \mathrm{Ma} ; 1070-1050 \mathrm{Ma}$; $1030-1000 \mathrm{Ma}$

Central Metasedimentary Belt:

Adirondack Lowlands $1170-1130 \mathrm{Ma}$

Frontenac domain $\quad 1175-1150 \mathrm{Ma}$

Sharbot Lake domain ca. $1152 \mathrm{Ma}$

Elzevir domain: $\quad 1240 \mathrm{Ma} ; 1060-1020 \mathrm{Ma}$

Bancroft domain: $\quad$ ca. $1150 \mathrm{Ma} ; 1045-1030 \mathrm{Ma}$

Central Gneiss Belt: $\quad$ ca. $1450 \mathrm{Ma}$; ca. $1150 \mathrm{Ma}$;

Grenville Front

Tectonic Zone ca. $1000 \mathrm{Ma}$
\end{abstract}

Combination of mineral ages with results from thermobarometry indicates that metamorphic pressures and temperatures recorded by thermobarometers were reached polychronously in the different domains that are separated by major shear zones. Some of these shear zones such as the Robertson Lake shear zone and the CarthageColton shear zone represent major tectonic boundaries. The Grenville Orogen is made up of a collage of crustal terranes that have distinct thermal and tectonic histories and that were accreted laterally by tectonic processes

Correspondence to: K. Mezger at Max-Planck-Institut für Chemie analogous to those observed along modern active continental margins. The subsequent history of the orogen is characterized by slow time-integrated cooling rates of $3 \pm 1{ }^{\circ} \mathrm{C} / \mathrm{Ma}$ and denudation rates of $120 \pm 40 \mathrm{~m} / \mathrm{Ma}$.

\section{Introduction}

Studies of Phanerozoic orogenic belts have revealed two major tectonic processes involved in the formation of mountain belts: lateral accretion of terranes commonly along strike-slip faults and vertical growth as a result of reverse faulting (i.e., stacking of thrust sheets). Lateral accretion of terranes is an important process for the growth of the western part of the North American continent (e.g., Coney et al. 1980; Saleeby 1983). The collision of continental blocks with resulting formation of nappes that may be transported over large distances and can be stacked to significant height is currently the most important process for the evolution of the Himalayan fold belt (e.g., Allègre et al. 1984). The formation of most Phanerozoic orogenic belts generally can be described using some combination of these two end-member processes (Laubscher and Bernoulli 1982; Hatcher 1989; Sengör 1991).

The understanding of the evolution of young orogenic belts is quite advanced, because currently active geological phenomena such as volcanism and seismicity can be integrated with known plate kinematics and tectonic features. In addition, the possibility of precise relative dating using the fossil record and paleomagnetic studies in Phanerozoic orogenic belts has led to accurate reconstructions of paleogeographic positions and major tectonic processes based on their influence on the sedimentary record. Such diverse constraints permit detailed descriptions of the important orogenic processes in Phanerozoic mountain belts. However, most information on orogenic processes is derived from rocks of relatively shallow crustal levels. In contrast, reconstruction of the histories of Precambrian orogens that developed during the major part of Earth history is hampered by lack of constraints from precise chronological data on the timing of ancient tectonic events. Sediments derived from the 
erosion of ancient orogens may not be preserved to allow inferences about the syn- to post-tectonic evolution of these mountain belts. In addition, most Precambrian belts are deeply eroded. Exposed middle crustal rocks have undergone medium to high grade metamorphism so that a detailed understanding of orogenic processes is difficult to obtain. Therefore, new approaches are necessary in order to delineate the history of these Precambrian mountains belts.

With improvements in a variety of techniques in isotope geochemistry it is now possible to obtain precise age information on the timing of geologic events and the rate of important processes during Precambrian orogenies (e.g., Krogh 1982; Vance and O'Nions 1989; Christensen et al. 1989; Davis et al. 1990; Mezger 1990), and to unravel the detailed tectonic histories of ancient mountain belts (e.g., Hoffman and Bowring 1984; Krogstad et al. 1989). In this paper we present high precision $\mathrm{U}-\mathrm{Pb}$ ages on sphene, monazite and rutile and use them to reconstruct the thermal and tectonic history of the Grenville Orogen of Ontario, Canada.

\section{Geological setting}

The Grenville Orogen represents one of the oldest linear orogenic belts stretching from Newfoundland in the north through eastern Canada, the eastern United States to Texas and central Mexico in the south. The largest exposure of rocks of Grenvillian age (i.e., rocks that yield $\mathrm{K}$-Ar ages of approximately 0.9 to $1.1 \mathrm{Ga}$; Stockwell 1964) is in eastern Canada and northern New York State. In addition, there are exposed inliers of rocks of Grenvillian age in the Appalachian Orogen from New York to Tennessee. Smaller outcrops occur in Texas and Mexico (e.g., Bartholomew et al. 1984; Patchett and Ruiz 1987). The exposed Oaxaca complex in Mexico may represent the southern termination of this long orogenic belt, although further possible continuations of this belt may have been identified in Columbia (Priem et al. 1989) and Antaretica (Hoffman 1991; Moores 1991).

The discussion in this paper concentrates on an E-W cross section through the Grenville Orogen in southern Ontario. In this area the Grenville Orogen can be divided into four major tectonic belts that strike approximately parallel to the orogen and are separated by ductile shear zones. The major units are the Grenville Front Tectonic Zone, the Central Gneiss Belt, the Central Metasedimentary Belt and the Central Granulite Terrane (Fig. 1) (WynneEdwards 1972; Davidson 1984a, b). The Grenville Front Tectonic Zone forms the transition zone between the Archean Superior Province or the early Proterozoic Southern Province with the Grenville Orogen. The rocks within this zone consist of units that yield Archean ages and units with Grenvillian ages (Easton 1986; Gariépy et al. 1990). To the SE the Central Gneiss Belt is dominated by upper amphibolite and granulite facies rocks of igneous origin and is further subdivided into domains that are separated by ductile shear zones (Davidson 1984a, 1984b; Culshaw et al. 1988). Metasedimentary rocks are subordinate in this belt. The Central Metasedimentary Belt is dominated by greenschist to granulite facies rocks of sedimentary and volcanic origin. This belt can be subdivided into the Bancroft, Elzevir, Sharbot Lake, Frontenac domains and the Adirondack Lowlands. These domains are also separated by ductile shear zones (Davidson 1984a, 1986; Hanmer 1988; Ontario Geological survey 1991). The Central Granulite Terrane is the most easterly exposed domain in the contiguous southern Grenville Orogen and is represented by the Adirondack Highlands. Here the dominant rock types are meta-igneous gneisses, including large anorthosite massifs. The thermal evolution of this domain together with the Lowlands recently has been discussed by McLelland et al. (1988) and Mezger et al. (1991a).

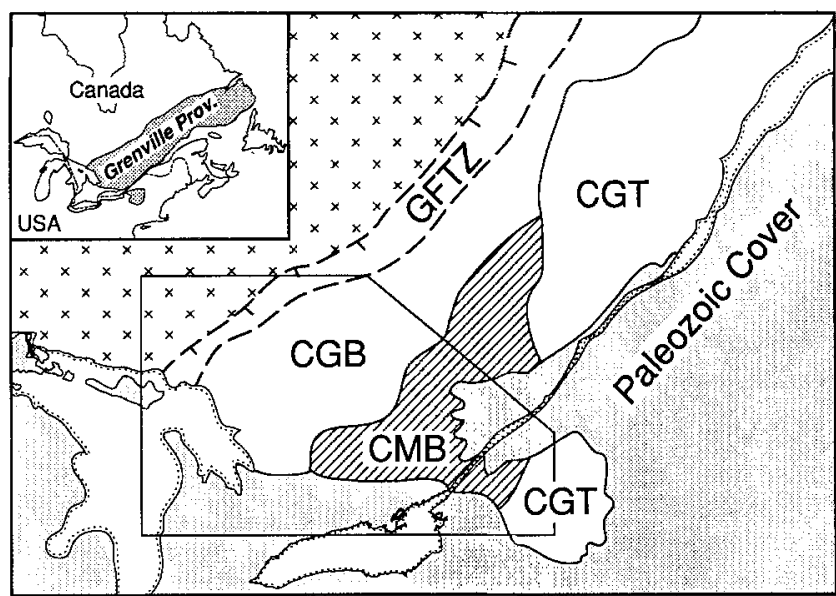

Fig. 1. Generalized tectonic map of the southern parts of the Grenville Orogen showing large scale subdivisons: $C G T$, Central Granulite Terrane; $C M B$, Central Metasedimentary Belt; $C G B$, Central Gneiss Belt; GFTZ, Grenville Front Tectonic Zone

Petrographic evidence and mineral assemblages indicate that the shear zones separating the major domains within the Grenville Orogen were active at different times during the orogenic cycle. Some like the Parry Sound shear zone and the Carthage-Colton shear zone were active while the terrane was undergoing amphibolite to granulite facies metamorphism as indicated by the mineral assemblages within the shear zones (Geraghty et al. 1981; Tuccillo et al. 1992). Others like the Bancroft shear zone show evidence for deformation during peak metamorphism and shortly thereafter (van der Pluijm and Carlson 1989; Mezger et al. 199lb). However, the amount of displacement across these shear zones is uncertain and in some cases the sense of movement is not known. Significant vertical displacement across some of these boundaries is indicated by changes in metamorphic grade (Davidson 1986). However, pressure estimates based on metamorphic mineral assemblages across most of the major shear zones do not show measurable vertical displacements within the uncertainty $( \pm 1 \mathrm{kbar}$ or about $\pm 3 \mathrm{~km}$ ) of the geobarometers (Moecher et al. 1988; Anovitz and Essene 1990), except for the boundary between the Central Metasedimentary and Central Gneiss Belt (Fig. 2) where metamorphic pressures apparently increase over a short distance from about $6 \mathrm{kbar}$ in the Bancroft domain to about $8 \mathrm{kbar}$ in the eastern Central Gneiss Belt.

\section{Analytical techniques}

Sphenes were separated from calc-silicate gneisses, marbles, amphibolites, granites, syenites, skarns and pegmatites. Most sphenes were large enough $(5-30 \mathrm{~mm})$ that individual crystals could be broken off the hand specimen. The large grains were crushed and material was taken preferentially from the core. Single crystals were examined for color zonation to distinguish core from rim material. Rock samples that contained smaller sphenes $(<2 \mathrm{~mm})$ were crushed and the sphenes extracted using heavy liquids and a Frantz Isodynamic magnetic separator. In the case of marbles the calcite was dissolved in about $3 \mathrm{M} \mathrm{HCl}$ prior to heavy liquid separation. Preferentially transparent and inclusion-free mineral grains were hand picked under a binocular microscope for isotope analysis. The monazites were separated from metapelites using standard heavy liquid and magnetic techniques.

The sphene separates and the rutile were washed in warm, twice distilled $2 \mathrm{M} \mathrm{HCl}$ for about $20 \mathrm{~min}$ to remove surface contamination. Monazite was washed in warm purified water. All minerals were spiked with a mixed ${ }^{205} \mathrm{~Pb} /{ }^{235} \mathrm{U}$ tracer before dissolution. All minerals were digested in $3 \mathrm{ml}$ screw-top Tefion $\mathrm{PFA}^{\mathrm{R}}$ vials inside 


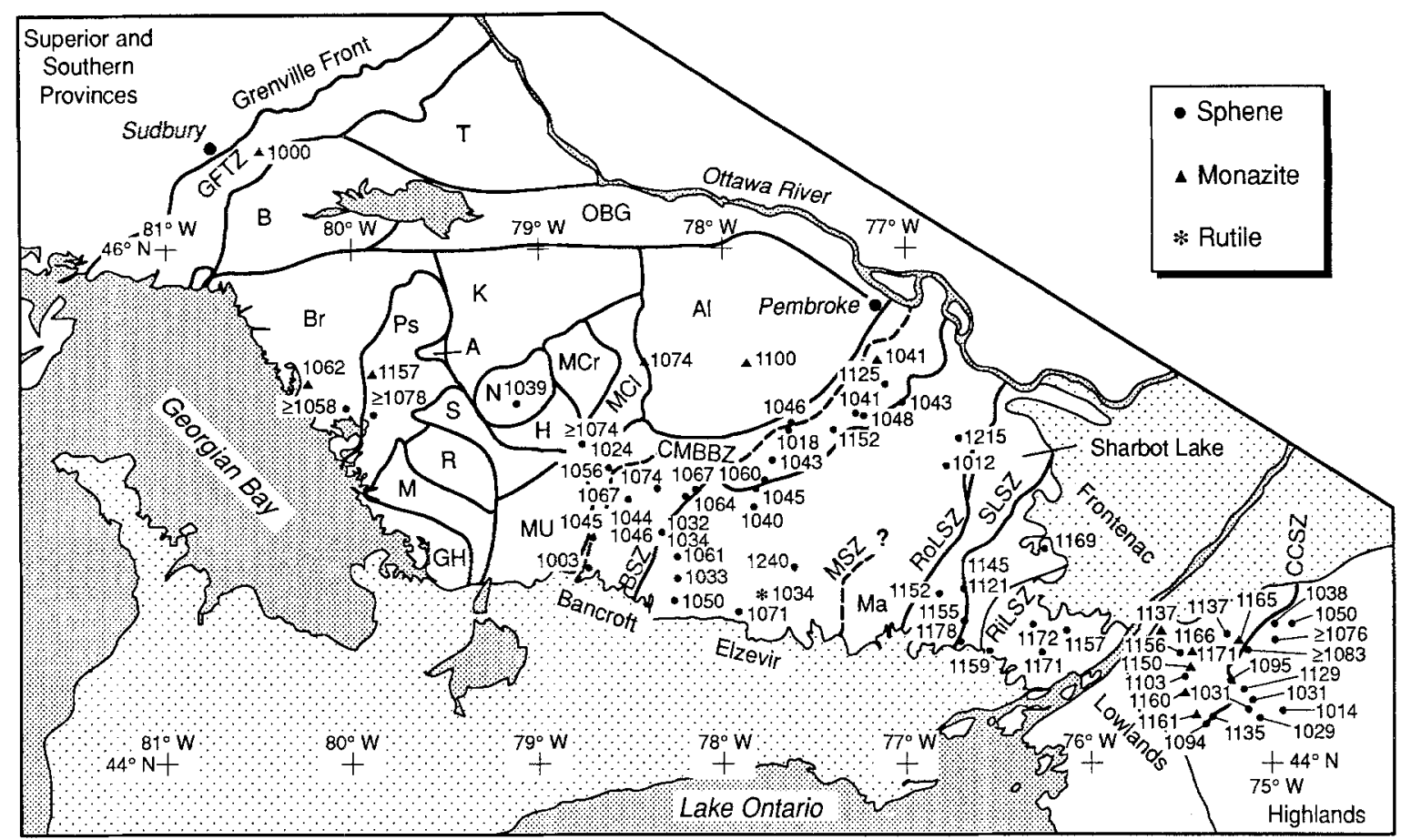

Fig. 2. Locations and ages of the minerals used for $\mathrm{U}-\mathrm{Pb}$ dating (Table 1). Additional ages from Davis and Bartlett (1988), and Tuccillo et al. (1992). The ages for the Adirondacks are from Mezger et al. (1991a, 1992). Also shown are the major faults and shear zones discussed in the text. CCSZ, Carthage-Colton shear zone; RiLSZ, Rideau Lake shear zone; RoLMZ, Robertson Lake shear zone; SLSZ, Sharbot Lake shear zone; MSZ, Mooroton shear zone; BSZ, Bancroft shear zone; GFTZ, Grenville Front Tectonic Zone; T, Tomiko domain; $B$, Burwash domain; $B r$, Britt domain; $O B G$,
Ottawa-Bonnechere Graben; PS, Parry Sound domain; K, Kiosk subdomain; $A$, Ahmic subdomain; $S$, Seguin subdomain; $R$, Rosseau subdomain; $M$, Moon River subdomain; $G H$, Go Home subdomain; $M u$, Muskoka domain; $A$, Algonquin domain; $M C r$, McCraney subdomain; $M C l$, McClintock subdomain; $N$, Novar subdomain; $H$, Huntsville subdomain. $C M B B Z$, Central Metasedimentary Belt Boundary Zone. The dotted pattern indicates the extent of the EoCambrian to Phanerozoic sediments overlying the Grenville basement
Krogh-style Teflon ${ }^{\mathrm{R}}$ or Parr $^{\mathrm{R}}$ bombs at $210^{\circ} \mathrm{C}$. Sphene was dissolved in a mixture of concentrated $\mathrm{HF}$ and $\mathrm{HNO}_{3}$, monazite in a mixture of concentrated $\mathrm{HCl}$ and $\mathrm{HNO}_{3}$, and rutile in a mixture of concentrated $\mathrm{HF}$ and $\mathrm{H}_{2} \mathrm{SO}_{4}$. After evaporation, the sphene and rutile samples were dissolved in $2 \mathrm{M} \mathrm{HCl}$ for ion exchanges chromatography. The $\mathrm{Pb}$ was separated using $\mathrm{HCl}-\mathrm{HBr}$ chemistry and the $\mathrm{U}$ by $\mathrm{HCl}-\mathrm{HNO}_{3}$ chemistry using BioRad $1-\mathrm{X} 8$ resin (Tilton 1973; Manhès et al. 1984; Mattinson 1986).

For samples that yielded sphenes with ${ }^{206} \mathrm{~Pb} /{ }^{204} \mathrm{~Pb}$ less than about 500 and where available, leached cogenetic K-feldspar was analyzed for its $\mathrm{Pb}$ isotope composition (C. P. DeWolf and $\mathrm{K}$. Mezger, in preparation). The rock was crushed to 0.5 to $0.2 \mathrm{~mm}$ and the K-feldspar separated with heavy liquids. About 5 to $30 \mathrm{mg}$ of fresh, inclusion-free fragments were hand picked under the binocular microscope. These were washed in a mixture of boiling $6 \mathrm{M} \mathrm{HNO}_{3}$ and $6 \mathrm{M} \mathrm{HCl}$ for at least $30 \mathrm{~min}$ and then leached with $\mathrm{HF}$ as described in Mezger et al. (1989a). The Pb was separated by HCl$\mathrm{HBr}$ chemistry. Whenever possible the $\mathrm{Pb}$ isotope for the minerals given in Table $\mathrm{I}$ were corrected for initial $\mathrm{Pb}$ using the $\mathrm{Pb}$ isotope ratios obtained from the feldspar residue after at least two leaching steps. For samples from which no feldspar could be obtained an average value characteristic for the area was used.

For isotope measurements, $\mathrm{Pb}$ was loaded on a single Re filament using the phosphoric acid-silica gel technique (Cameron et al. 1967). Sample sizes varied from 1 to $100 \mathrm{ng}$ of $\mathrm{Pb}$. For analysis the $\mathrm{U}$ was loaded with phosphoric acid between graphite layers on a single $\operatorname{Re}$ filament and was run as the metal. The total procedural blank for $\mathrm{Pb}$ was 40 to $150 \mathrm{pg}$ and $<20 \mathrm{pg}$ for $\mathrm{U}$. All analyses were performed in the Radiogenic Isotope Geochemistry Laboratory at the University of Michigan using two VG sector multicollector mass spectrometers equipped with 6 and 7 Faraday collectors and a Daly collector. Most $\mathrm{U}$ and $\mathrm{Pb}$ analyses were performed in static multicollector mode. All $\mathrm{Pb}$ isotope ratios were corrected with a mass discrimination factor of $0.13 \%$ per AMU based on analyses of NBS standards SRM 981 and SRM 983. The reproducibility of the ${ }^{207} \mathrm{~Pb} /{ }^{205} \mathrm{~Pb}$ for the standard was $0,06 \%(2 \sigma)$. Based on replicate analyses of NBS-SRM U-500 the discrimination factor for U was $0.1 \%$ to $0.2 \%$ per AMU depending on the batch of graphite solution used. Decay constants are those recommended by the International Union of Geological Sciences (Steiger and Jäger 1977). All data were reduced using the program Pb-DAT (Ludwig 1980, 1982) rewritten for an IBM PC. The uncertainties reported for the $\mathrm{U} / \mathrm{Pb}$ and ${ }^{207} \mathrm{~Pb} /{ }^{206} \mathrm{~Pb}$ ages $(2 \sigma)$ include the reproducibility of the standard, common $\mathrm{Pb}$ and blank corrections as well as within-run uncertainties and the uncertainties in the $\mathrm{U} / \mathrm{Pb}$ of the spike.

\section{Petrography}

In most unsheared marbles, sphenes are typically several mm large, and some can be up to $30 \mathrm{~mm}$ in their longest dimension. These large sphenes are typically concentrated around silicate inclusions or silicate layers within a matrix dominated by calcite. Some of the felsic silicate inclusions and layers may represent former ash flow tuffs; mafic silicate inclusions may represent remnants of basaltic flows or dikes. In the Bancroft domain of the Central Metasedimentary Belt large $(>10 \mathrm{~mm})$ sphenes are common in skarns along with amphibole, pyroxene, biotite and calcite. In almost all marble mylonites (e.g., sample GO5b, 90-45), but only in a few coarse pristine marbles (e.g., sample 90-18), sphene was found as small 
$(<2 \mathrm{~mm}$ ) ellipsoidal grains disseminated throughout the rock. Disseminated sphene occurs together with epidote and pyroxene in calcsilicate gneisses. Although amphibolites are widespread throughout the Grenville Orogen, only some of those that experienced upper amphibolite to granulite facies were found to contain sphenes $(<2 \mathrm{~mm})$ that have sufficiently high $\mathrm{U} / \mathrm{Pb}$ to yield reliable ages. Syenitic dikes can have several modal percent of sphene typically together with allanite. Pegmatites were widespread, especially in the Bancroft domain, and many of them contain sphenes (up to $10 \mathrm{~cm}$, sample XX) together with quartz, K-feldspar, calcite, apatite and rare-earth-element- and $\mathrm{U}$-rich minerals. The analyzed monazites were extracted from garnet-biotite gneisses in which they occur typically as inclusions in larger metamorphic minerals such as garnet, sillimanite and biotite. The rutile was isolated from a coarsegrained plagioclase-calcite-hornblende vein within a fine-grained amphibolite.

\section{Closure temperatures}

For interpretation of the mineral ages, information is needed on the closure temperatures for $\mathrm{U}-\mathrm{Pb}$ diffusion in the different phases used for dating. By comparing closure temperatures $(T \mathrm{c})$ with peak temperatures recorded by the geothermometers it is possible to evaluate whether a mineral age records an event during prograde metamorphism or whether it yields information on the cooling history of the orogenic belt. For temperature estimates the regional temperature contours of Anovitz and Essene (1990) and Bohlen et al. (1986) were used. Geothermometry on the sphene bearing samples is not possible due to the lack of suitable mineral assemblages.

The closure temperature for monazite is taken to be about $725^{\circ} \mathrm{C}$ (Copeland et al. 1988; Mezger et al. 1991a; Parrish 1991). The closure temperature for sphene is generally considered to be about 500 to $550^{\circ} \mathrm{C}$ (e.g., Mattinson 1978; Gascoyne 1986). However, more recent studies point towards a much higher $T \mathrm{c}$ in sphene (Heaman and Parrish 1991; Mezger et al. 1991a). When the ${ }^{40} \mathrm{Ar} /{ }^{39} \mathrm{Ar}$ ages for hornblende (Cosca et al. 1991, 1992) for the Grenville Orogen are compared with the $\mathrm{U}-\mathrm{Pb}$ sphene ages for the same samples or for equivalent areas it is always the case that the U-Pb sphene ages are significantly older, typically about $50 \mathrm{Ma}$. This provides strong evidence that the closure temperature of sphene is significantly higher than $480^{\circ} \mathrm{C}$, commonly taken for the ${ }^{40} \mathrm{Ar} /{ }^{39} \mathrm{Ar}$ system in slowly cooled metamorphic hornblende (Harrison 1981; Baldwin et al. 1990). The higher closure temperature for sphene is also supported by the data presented here, particularly by the ages obtained in the Bancroft domain. In this domain sphenes from igneous rocks and skarns record the time of magmatic activity, some sphenes from a marble (sample 89-13) record an early metamorphism that is older than the regional metamorphism that reached peak metamorphic temperatures up to ca. $650^{\circ} \mathrm{C}$ (Anovitz and Essene 1990). This is strong evidence that the closure temperature for most sphenes analyzed in this study is at least $\mathrm{ca} .650^{\circ} \mathrm{C}$. The closure temperature for $\mathrm{U}-\mathrm{Pb}$ in sphene seems to be a function of grain size, but this relationship is not well understood and it is difficult to assign a specific closure temperature to each sphene investigated in this study. A comparison of sphene ages with ages of other minerals in the Adirondacks and reevaluation of sphene data from the contact aureole of the Duluth Gabbro (Hanson et al. 1971) led to the suggestion that the closure temperature for sphene is about 550 to $650^{\circ} \mathrm{C}$ depending on the grain size (Mezger et al. 1991a). Since most sphenes analyzed for this study were $\geq 10 \mathrm{~mm}$ the closure temperature is estimated to be about $650^{\circ} \mathrm{C}$. For the small sphenes found in some marbles, calc-silicate gneisses and particularly in marble mylonites the closure temperature is taken as about $600^{\circ} \mathrm{C}$.

The analyzed rutile needles were about $1 \mathrm{~mm}$ in diameter and up to $5 \mathrm{~mm}$ long. Their closure temperature is taken to be about $500{ }^{\circ} \mathrm{C}$ (Mezger et al. 1989b). Comparison of closure temperatures with peak metamorphic temperatures reported by Anovitz and Essene (1990) indicates that the sphenes from the Central Gneiss Belt record cooling ages following granulite facies metamorphism. However, the monazites from the southern Central Gneiss Belt may record growth ages and the sphenes cooling ages. In the Frontenac domain the regional metamorphic temperatures reached at least $620^{\circ}$ to $700^{\circ} \mathrm{C}$ (Anovitz and Essene 1990) and sphenes in this area therefore either record growth ages or were closed to diffusion soon after peak metamorphism. This interpretation is consistent with the agreement of the oldest sphene ages and the U-Pb growth ages obtained on zircons from synmetamorphic intrusions (van Breemen and Davidson 1988; Marcantonio et al. 1990) in the Frontenac domain. Since the Elzevir and Bancroft domains as well as the Central Metasedimentary Belt Boundary Zone experienced only greenschist to amphibolite facies conditions the sphenes in these domains record the time of their growth.

\section{Results}

The analytical results and ages obtained from the different minerals are listed in Table 1 and the locations of the samples are shown in Fig. 2. Exact sample locations are given in the appendix. Most sphenes yield concordant $\mathrm{U}-\mathrm{Pb}$ ages and therefore the ${ }^{207} \mathrm{~Pb} /{ }^{206} \mathrm{~Pb}$ ages are used as the real ages. It should be kept in mind that $\mathrm{Pb}$ loss during the first several tens of Ma after sphene growth is very difficult to detect and cannot be excluded a priori. For sample 89-13 concordant but distinct ages of 1141 $\pm 1 \mathrm{Ma}$ and $1152 \pm 2 \mathrm{Ma}$ were obtained for rim and core fragments, respectively. This may indicate that this sphene crystal lost some $\mathrm{Pb}$ and that the age for the core may have to be interpreted as a minimum age rather than a growth or cooling age. However, the consistency of the sphene ages from within the same tectonic units indicates strongly that early $\mathrm{Pb}$ loss is not very important, unless it affected all sphenes to about the same extent. Considering that the sphenes were taken from different rock types and have different sizes such a uniform Pb-loss pattern is unlikely.

The sphenes have variable ${ }^{208} \mathrm{~Pb} /{ }^{206} \mathrm{~Pb}$ ranging from 0.0854 to 1.9456 and show no correlation between their $\mathrm{U} / \mathrm{Th}$ and common $\mathrm{Pb}$ concentrations, indicating that these variables are dominated by the host rock chemistry rather than the crystal structure of the sphenes. Sphenes from marbles have among the highest and the lowest 
Table 1. Analytical data

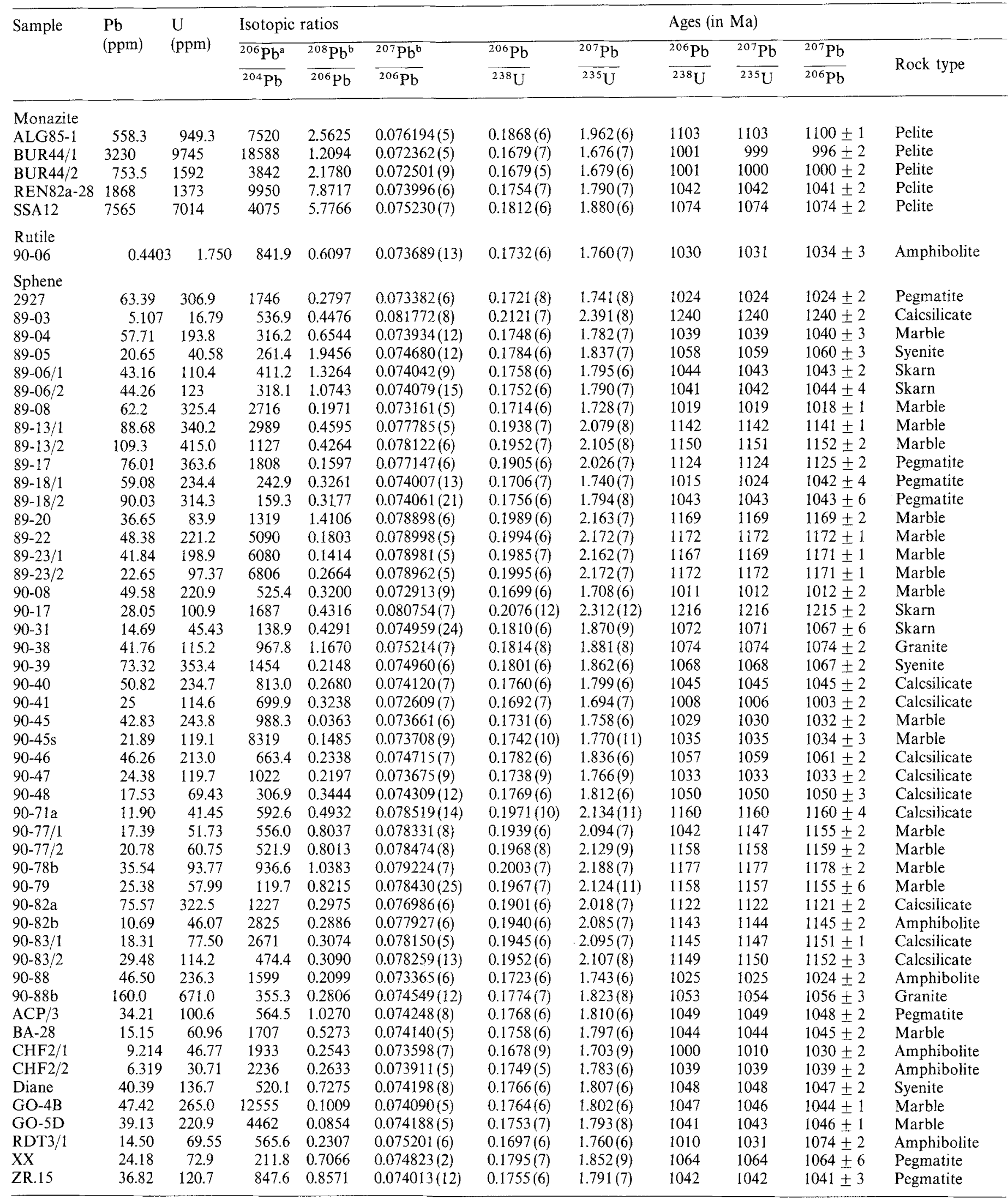

${ }^{a}$ Measured ratio

${ }^{\mathrm{b}}$ Ratio corrected for mass fractionation, blank and common $\mathrm{Pb}$ 
$\mathrm{U} / \mathrm{Pb}$ (Table 1). Lower values are typical for sphenes from granitic rocks and some amphibolites, but there is no consistent correlation between rock type and $\mathrm{U} / \mathrm{Pb}$ in the sphene. In general, the dark and clear crystals have the highest $\mathrm{U}$ concentrations and also the highest $\mathrm{U} / \mathrm{Pb}$ and are therefore the most useful sphenes for dating. Light colored and cloudy grains typically have low $U$ concentrations as well as low $\mathrm{U} / \mathrm{Pb}$. The coloration is most likely due to incorporation of $\mathrm{Fe}$ rather than radiation damages and metamictization by the decay of $U$ or Th.

The monazites have characteristically high ${ }^{208} \mathrm{~Pb} /$ ${ }^{206} \mathrm{~Pb}$ and high $\mathrm{U}$ concentrations. The $\mathrm{Pb}$ and $\mathrm{U}$ concentrations for monazites given in Table 1 have to be considered approximate values since the samples used for the analyses were too small to obtain their precise weight. The $\mathrm{U}-\mathrm{Pb}$ ages obtained for a given mineral differ systematically between the various domains of the Central Metasedimentary Belt and the Southern Central Gneiss Belt (Fig. 2).

\section{Grenville Front Tectonic Zone and Central Gneiss Belt}

A monazite sample (sample BUR 44) from the Grenville Front Tectonic Zone yields an age of $1000 \mathrm{Ma}$. This age, which is the youngest so far recorded for monazite in the Grenville Orogen of Ontario, is very similar to K-Ar ages obtained for hornblendes and biotites within this area (see summary by Easton 1986). It most likely dates the last major tectonic movement along this prominent fault zone. A monazite from the Parry Sound domain yields an age of $1157 \mathrm{Ma}$ (Tuccillo et al. 1992). Sphenes and a monazite from the southern Central Gneiss Belt yield ages between 1100 and $1040 \mathrm{Ma}$ (Table 1). Since peak metamorphic temperatures in this area reached 700 to $800^{\circ} \mathrm{C}$ (Anovitz and Essene 1990), the U-Pb ages of monazite may record growth or cooling ages while sphenes record only cooling ages.

\section{Central Metasedimentary Belt Boundary Zone and Bancroft domain}

The majority of sphenes from the Bancroft domain and Central Metasedimentary Belt Boundary Zone, which grew as a result of igneous activity (pegmatites, skarns, syenite dikes), fall in the range from 1074 to $1045 \mathrm{Ma}$. They are older than sphenes of unambiguously metamorphic origin (marbles, calc-silicate gneisses) that yield ages from 1045 to $1030 \mathrm{Ma}$. The latter ages therefore are considered to date the time interval for regional metamorphism in the Bancroft domain. Sphenes extracted from marble mylonites within the Bancroft shear zone yield ages that are identical to unsheared metamorphic sphene, supporting the interpretation of this fault as a synorogenic collapse structure (Mezger et al. 1991b). Ages from within the Central Metasedimentary Belt Boundary Zone are similar to ages obtained for the Bancroft domain and indicate a close affinity of these two tectonic units.

Within the Bancroft domain one sphene from a marble and of unambiguously metamorphic origin gives an age of $1152 \mathrm{Ma}$ for the core and $1141 \mathrm{Ma}$ for the rim, and a sphene from a syenite dike yields a similarly old age of $1125 \mathrm{Ma}$. Although a large number of sphenes have been dated throughout the Bancroft domain, these old ages were found only in the northeastern part of the area. Comparable ages were also obtained from sphenes in the Frontenac domain (Table 1) and the Adirondack Lowlands (Mezger et al. 1991a), from zircons in the Adirondack Highlands (McLelland et al. 1988), the Parry Sound domain (van Breemen et al. 1986) and shear zones in the Central Metasedimantary Belt Boundary zone (van Breemen and Hanmer 1986) and from baddeleyites from the Algonquin, Segiun and Go Home domains in the Central Gneiss Belt (Davidson and van Breemen 1988; van Breemen and Davidson 1990).

\section{Elzevir domain}

A large number of igneous intrusions within the Elzevir domain have been dated precisely using $\mathrm{U} / \mathrm{Pb}$ in zircons (Heaman et al. 1986; Davis and Bartlett 1988; van Breemen and Davidson 1988; Lumbers et al. 1990). The majority of the plutons yielded ages of about 1280 to $1240 \mathrm{Ma}$. One sphene sample from a calc-silicate schist (sample 89-03) in the central Elzevir domain gives an age of $1240 \mathrm{Ma}$ and a sphene from a skarn (sample 90-17) in the vicinity of the Black Donald pluton yields an age of $1215 \mathrm{Ma}$ (Fig. 2, Table 1). These sphenes most likely grew during widespread magmatic activity in the Elzevir domain and do not record a regional medium to high grade metamorphic episode. These sphenes were not reset during later regional metamorphism because the metamorphic grade reached only greenschist facies conditions in this area which was insufficient to reset the $\mathrm{U}-\mathrm{Pb}$ systematics of sphene. Davis and Bartlett (1988) obtained $\mathrm{U}-\mathrm{Pb}$ sphene ages of $1071 \mathrm{Ma}$ (Fig. 2) for the 1287 to $1240 \mathrm{Ma}$ old Belmont Lake metavolcanic complex and the $1088 \mathrm{Ma}$ old Belmont granite in the southwestern Elzevir domain, they suggested that these sphenes record cooling after the last magmatic activity in this area at $1088 \mathrm{Ma}$. The sphene ages of 1061 to $1012 \mathrm{Ma}$ (Fig. 2) are interpreted to date the regional metamorphism in the Elzevir domain, because these samples were collected away from plutons and show fabrics that support synmetamorphic deformation. The metamorphic temperatures and pressures compiled by Anovitz and Essene (1990) from a variety of geothermometers and geobarometers correspond to this regional metamorphic event. The timing of peak metamorphism in the Elzevir domain coincides with that in the Bancroft domain, suggesting that these two domains had been amalgamated to a single domain at this time.

\section{Sharbot Lake and Frontenac domains}

Sphenes from the Frontenac domain yield ages ranging from 1178 to $1157 \mathrm{Ma}$ and are therefore up to $50 \mathrm{Ma}$ older than sphenes from the lithologically and structurally very similar Adirondack Lowlands. Several granitic intrusions from the Frontenac domain yielded zircons with crystallization ages of 1173 to $1162 \mathrm{Ma}$ (Marcantonio 
et al. 1990; van Breemen and Davidson 1990) and are up to $25 \mathrm{Ma}$ older than granitic intrusions from the Lowlands (McLelland et al. 1988). The similar ages of the metamorphic sphenes and the igneous zircons indicate that regional metamorphism and magmatism were contemporaneous. The magmas could have been an important heat source that promoted upper amphibolite to granulite facies metamorphism in this domain. The mineral ages in the Adirondack Lowlands are younger than in the Frontenac domain. This difference may be due to a southeastward migration of the heat source. Despite differences in closure temperature the similar ages of zircons and sphenes from the Frontenac domain, and the high peak metamorphic temperature $\left(620-700^{\circ} \mathrm{C}\right.$, Anovitz and Essene 1990) require rapid initial cooling following the intrusion of the granitoids during peak metamorphism. However, time-integrated cooling rates, obtained from $\mathrm{U}-\mathrm{Pb}$ zircon and sphene ages combined with ${ }^{40} \mathrm{Ar} /{ }^{39} \mathrm{Ar}$ hornblende ages (Cosca et al. 1991, 1992) and peak metamorphic temperatures, are only in the range of 1 to $4^{\circ} \mathrm{C} / \mathrm{Ma}$.

Fine grained sphene $(<0.5 \mathrm{~mm})$ from two different sample from the Sharbot Lake shear zone that separates the Sharbot from the Frontenac domain yield ages of $1125 \mathrm{Ma}$ and $1145 \mathrm{Ma}$, respectively, and are slightly discordant. These minimum ages are younger than those from unsheared rocks in the Frontenac domain. This discrepancy can be explained by their much smaller grain size but could also be caused by shearing along the Sharbot Lake shear zone.

Sphenes are rare in the Sharbot Lake domain and therefore only one sphene sample (90-83) was dated and it yields an age of $1153 \mathrm{Ma}$. This age is similar to those obtained from the Frontenac domain and Adirondack Lowlands (Mezger et al. 1991a) and supports a close affinity of the Sharbot Lake and Frontenac domains in terms of their thermal histories.

\section{Discussion}

\section{Significance of shear zones}

The ages shown in Fig. 2 and Table 1 combined with data from the literature (Heaman et al. 1986; van Breemen et al. 1986; van Breemen and Hanmer 1986; Easton 1986; Davis and Bartlett 1988; McLelland et al. 1988; Davidson and van Breemen 1988; van Breemen and Davidson 1988, 1990; McLelland and Chiarenzelli 1989, 1990; Marcantonio et al. 1990; Lumbers et al. 1990; Mezger et al. 1991a, b, 1992; Cosca et al. 1991, 1992) provide strong evidence that the Central Gneiss Belt and the Central Granulite Terrane are polymetamorphic terranes. In contrast, all domains within the Central Metasedimentary Belt except for a small area in the northwestern Bancroft domain seem to have undergone only one episode of medium to high grade regional metamorphism. The mineral ages presented here together with $P-T$ estimates for the metamorphism in the Grenville Orogen underscore the importance of some of the shear zones that have been mapped throughout the Grenville Orogen. The coinci- dence of age discontinuities with structural boundaries indicates that the different terranes had distinct thermal histories. Despite these discontinuities the pressure and temperature distribution for the Grenville Orogen of Ontario (Anovitz and Essene 1990) and the Adirondacks (Bohlen et al. 1986) can be contoured across many faults and yield regular patterns. However, the age information presented in this paper leads to the conclusion that these pressures and temperatures were not reached at the same time throughout the area. Therefore, the regular patterns for peak metamorphic conditions were established in different domains at different times and do not represent an isochronous glimpse of the metamorphic history of the Grenville Orogen.

\section{Grenville Front Tectonic Zone and Central Gneiss Beit}

As shown by Davidson $(1984 a, b ; 1986)$ the Central Gneiss Belt is made up of different thrust nappes. Suture zones within the Central Gneiss Belt were described by Dickin and McNutt (1989), Dickin et al. (1990) and Tuccillo et al. (1992) and support a complex history for this part of the Grenville Orogen. Due to the high metamorphic temperatures reached in large parts of the Central Gneiss Belt (Anovitz and Essene 1990) a tectonic reconstruction using sphenes and monazite only can be made for the postmetamorphic history. The data base for the Central Gneiss Belt is limited. Zircon, baddeleyite, sphene and monazite ages obtained from this area (Table 1, Davidson and van Breemen 1988; Tuccillo et al. 1992) indicate that parts of this domain underwent high grade metamorphism at about $1150 \mathrm{Ma}$ and were overprinted again at about 1070 to $1050 \mathrm{Ma}$. The metamorphic pressures and temperatures obtained by Anovitz and Essene (1990) most likely correspond to the last of these metamorphic episodes that reached upper amphibolite to granulite grade throughout the Central Gneiss Belt. The ages suggest that the last high grade metamorphism in the Central Gneiss Belt occurred prior to the last metamorphism in the Bancroft and Frontenac domains (Fig. 2). Combined with the pressure gradient described in Anovitz and Essene (1990), this relationship supports the interpretation of the Central Metasedimentary Belt Boundary Zone as an important tectonic and thermal discontinuity. Thrusting of the Central Metasedimentary Belt over the Central Gneiss Belt occurred at ca. $1160 \mathrm{Ma}$ and $1060 \mathrm{Ma}$ as indicated by $\mathrm{U}-\mathrm{Pb}$ ages from syn-deformational pegamtites within the Central Metasedimentary Belt Boundary Zone (van Breemen and Hanmer 1986; McEachern et al. 1990). At least some of the domains within the Central Gneiss Belt may have been metamorphosed prior to $1150 \mathrm{Ma}$ (van Breemen et al. 1986; Tuccillo et al. 1992). Mineral ages obtained for the Britt domain provide evidence for a major tectonothermal episode at about $1450 \mathrm{Ma}$ and a later metamorphic overprint at ca. $1050 \mathrm{Ma}$ (Easton 1986; van Breemen et al. 1986; Tuccillo et al. 1992). The lack of evidence for a thermal event at about $1150 \mathrm{Ma}$ for the Britt domain is in striking contrast to the history of most other domains, which show evidence for this metamorphism in addition to the younger overprint at about 1070 to $1050 \mathrm{Ma}$ (Easton 1986; van Breemen et al. 1986). 
Thrusting of the Central Gneiss Belt onto the Superior and Southern Provinces along the Grenville Front Tectonic Zone lasted at least until about $1000 \mathrm{Ma}$ as shown by monazite ages from sample BUR 44 . The ages obtained for two different monazite grains from the same sample are similar to $\mathrm{K}-\mathrm{Ar}$ ages obtained on hornblende, biotite and muscovite and $\mathrm{Rb}$-Sr ages obtained on biotite and muscovite from within the Grenville Front Tectonic Zone (Easton 1986) and indicate rapid cooling and uplift for this area.

\section{Bancroft shear zone}

An important geologic discontinuity in the Grenville Orogen of Ontario occurs at the boundary between the Elzevir and the Bancroft domain of the Central Metasedimentary Belt. The Elzevir domain is characterized by a bimodal suite intruded by felsic plutons at ca. $1240 \mathrm{Ma}$, and the Bancroft domain is characterized by abundant amphibolites, marbles and skarns. These lithological differences between the two domains may be considered as an indication of their different geologic histories. The differences in the thermal evolution of the Bancroft and Elzevir domain indicate that they have distinct histories and that they were separate at least until $1120 \mathrm{Ma}$. Magmatism at ca. 1090 to $1080 \mathrm{Ma}$ occurring in the Elzevir domain (Corriveau 1990; Corriveau et al. 1990) is not recorded in the Bancroft domain and the abundant syenites and pegmatites that intruded the Bancroft domain from 1075 to $1045 \mathrm{Ma}$ (Table 1) have no known equivalents in the Elzevir domain. The oldest age of $1061 \mathrm{Ma}$ for a metamorphic sphene from the Elzevir overlaps with the youngest magmatic activity in the Bancroft domain and may indicate that the two domains were welded together at this time and that they shared a common history since then. This amalgamation at about $1060 \mathrm{Ma}$ coincides with a second episode of thrusting along the Central Metasedimentary Belt Boundary Zone that led to the movement of the Bancroft domain over the Central Gneiss Belt, as indicated by zircon U-Pb ages obtained from syn-deformational pegmatites in the Central Metasedimentary Belt Boundary Zone (van Breemen and Hanmer 1986). An earlier thrusting event along this fault has been dated at ca. $1160 \mathrm{Ma}$ (van Breemen and Hanmer 1986; McEachern et al. 1990), which coincides with the oldest sphene age (sample 89-13) from the NE Bancroft domain. The age of $1024 \mathrm{Ma}$ from a sphene extracted from an amphibolite (sample 90-88) within this tectonic zone and the age of $1003 \mathrm{Ma}$ from sphene in a marble (sample 89-41) indicate that the Central Metasedimentary Belt Boundary Zone was tectonically active much longer than the duration of amphibolite facies metamorphism in the Bancroft domain, which lasted from about 1045 to $1030 \mathrm{Ma}$ as shown by the ages obtained from metamorphic sphenes. The sphene ages in the western Elzevir domain indicate a somewhat longer interval for regional metamorphism lasting from 1061 to $1033 \mathrm{Ma}$. A sphene from the eastern Elzevir domain yields a metamorphic age of $1012 \mathrm{Ma}$, significantly younger than those from the western Elzevir domain. Hornblende ${ }^{40} \mathrm{Ar} /{ }^{39} \mathrm{Ar}$ ages (Cosca et al. 1991, 1992) are also younger in the eastern than in the western Elzevir domain and support the new subdivision within the Elzevir domain proposed by Easton (1992).

As shown by the ages of metamorphic sphenes and structural features from marble mylonites, syn-tectonic orogenic collapse occurred soon after thrusting along the Elzevir-Bancroft boundary and is synchronous with continued thrusting in the Central Metasedimentary Belt Boundary Zone. The extensional shear zone reactivated parts of the earlier thrust fault but also cut across the northern parts of the Elzevir domain (van der Pluijm and Carlson 1989; Mezger et al. 1991b). Deformation within the extensional shear zone lasted at least until about $1030 \mathrm{Ma}$ as indicated by the youngest sphene age from a sheared marble. Deformation within the Central Metasedimentary Belt Boundary Zone may have lasted until about $1003 \mathrm{Ma}$, similar to the last movements along the Grenville Front Tectonic Zone (Table 1; Fig. 2).

Combining the temperature estimates for peak metamorphism (Anovitz and Essene 1990) with U-Pb sphene ages from this study and ${ }^{40} \mathrm{Ar} /{ }^{39} \mathrm{Ar}$ hornblende ages (Cosca et al. 1991, 1992) yields cooling rates of about $16^{\circ} \mathrm{C} / \mathrm{Ma}$ for the western Elzevir domain in the vicinity of the Bancroft shear zone. These rapid initial cooling rates following the last thermal peak are consistent with rapid uplift due to the initiation of a major extensional shear zone (van der Pluijm and Carlson 1989; Mezger et al. 1991b).

\section{Mooroton shear zone}

As evident from the data of Cosca et al. $(1991,1992)$ there is a pronounced difference in the ${ }^{40} \mathrm{Ar} /{ }^{39} \mathrm{Ar}$ hornblende ages between the western and eastern Elzevir domain. The ages for hornblende from unsheared amphibolites in western Elzevir domain are $1021 \mathrm{Ma}$ and $1026 \mathrm{Ma}$, whereas the ages for hornblende from the southeastern part range from 942 to $919 \mathrm{Ma}$. However, both areas contain plutons that intruded at about $1240 \mathrm{Ma}$ (Davis and Bartlett 1988; van Breemen and Davidson 1988; Lumbers et al. 1990) and have sphenes of similar ages that formed in contact aureoles of these plutons (Fig. 2). It is suggested therefore that the eastern part of the Elzevir domain had the same early history but a different uplift history from the western part and is not a separate terrane. The eastern part of the Elzevir domain, called "Mazinaw terrane" by Easton and Ford (1991) but referred to as Mazinaw domain here (Fig. 2) is separated from the western part by the Mooroton shear zone. The western parts of the Elzevir domain are referred to as Grimsthorpe domain, Belmont domain and Harvey-Cardiff arch (Connelly 1985, Easton and Ford 1991). However, there is no need for this level of subdivision in this study and these domains will be treated as one tectonic unit here. The younger ${ }^{40} \mathrm{Ar} /{ }^{39} \mathrm{Ar}$ hornblende and $\mathrm{U}-\mathrm{Pb}$ sphene ages (sample 90-08) suggest that the southeastern part of the Elzevir domain was uplifted significantly more than the adjacent units of the western Elzevir domain. Assuming a geothermal gradient of $25^{\circ} \mathrm{C} / \mathrm{km}$ and a time integrated cooling rate of 2 to $3^{\circ} \mathrm{C} / \mathrm{Ma}$ the difference in the ${ }^{40} \mathrm{Ar} /{ }^{39} \mathrm{Ar}$ ages corresponds to about $10 \pm 2 \mathrm{~km}$ of differential uplift across this fault. 


\section{Robertson Lake shear zone}

A comparison of all the ages shown in Figs. 2 and 3 indicates that a major discontinuity in the mineral ages coincides with the Robertson Lake shear zone, which separates the Sharbot Lake from the Elzevir domain. These two domains experienced regional metamorphism at least $100 \mathrm{Ma}$ apart. Combining sphene data with ${ }^{40} \mathrm{Ar} /{ }^{39} \mathrm{Ar}$ (Cosca et al. 1991, 1992) and zircon data (Davis and Bartlett 1988; Lumbers et al. 1990; Marcantonio et al. 1990; van Breemen and Davidson 1990) reveals that the eastern part of the Elzevir domain experienced middle to upper amphibolite facies conditions during the time at which the Frontenac domain had already cooled to $\leq 350^{\circ} \mathrm{C}$. Although the U-Pb sphene ages do not show a systematic change from the southeastern Frontenac domain to the Sharbot Lake domain, the ${ }^{40} \mathrm{Ar} /{ }^{39} \mathrm{Ar}$ hornblende ages (Cosca et al. 1991, 1992) show an apparent younging from about $1115 \mathrm{Ma}$ in the central Frontenac domain to $1007 \mathrm{Ma}$ in the Sharbot Lake domain. However, this pattern may not indicate slower cooling rates for the western than for the eastern part. Two of the hornblende samples were taken from the Sharbot Lake shear zone and their ${ }^{40} \mathrm{Ar} /{ }^{39} \mathrm{Ar}$ ages may reflect resetting due to some late movement along this fault. The sample from the Sharbot Lake domain yields a ${ }^{40} \mathrm{Ar} /{ }^{39} \mathrm{Ar}$ hornblende age that is similar to values obtained for the western Elzevir domain and may therefore record an influence from the main regional metamorphism in the Elzevir domain that reset the ${ }^{40} \mathrm{Ar} /{ }^{39} \mathrm{Ar}$ hornblende age but not the $\mathrm{U}-\mathrm{Pb}$ sphene age.

The marked discontinuity in the sphene ages across the Robertson Lake shear zone reflects the different thermal and possibly tectonic histories of the Elzevir and Sharbot Lake/Frontenac domains. Further support for the interpretation of the Robertson Lake shear zone as a profound tectonic boundary comes from the comparison of all geochronological data currently available for the Grenville Orogen from the Adirondacks to the Central Gneiss Belt (e.g., Heaman et al. 1986; van Breemen et al. 1986; Easton 1986; McLelland et al. 1988; Davidson and van Breemen 1988; van Breemen and Davidson 1988, 1990; Lumbers et al. 1990; Marcantonio et al. 1990; Mezger et al. 1991a, b; Cosca et al. 1991, 1992). All domains in this transect except for the Elzevir and south- ern Bancroft domain, record magmatic or metamorphic ages of approximately 1170 to $1150 \mathrm{Ma}$. In contrast, the major magmatic event that occurred around $1240 \mathrm{Ma}$ (Heaman et al. 1986; Davis and Bartlett 1988; Lumbers et al. 1990) in the Elzevir domain is not known in any of the surrounding domains. Plutons of similar age are recorded in Tomiko domain (Lumbers et al. 1991) and the Adirondacks, but they are rare and are much smaller than in the Elzevir domain. The character of the magmatic activity is also quite different (McLelland and Chiarenzelli 1990). Therefore, temporal similarity may not indicate tectonic proximity. The unique character of the Elzevir domain may imply that the Elzevir and possibly parts of the southern Bancroft domain formed in complete isolation from the rest of now adjacent crustal segments in the Grenville Orogen. If so, the Elzevir domain may be truly suspect terrane, and the faults bounding the Elzevir domain may be interpreted as sutures that represent major tectonic boundaries separating terranes with distinct tectonothermal histories.

The importance of these possible sutures may be supported by the observation of a prominent magnetic anomaly that can be traced from northern Alabama through Tennessee, Pennsylvania and western New York (Committee for the Magnetic Anomaly Map of North America 1987). If extended further north, this anomaly cuts across the central parts of the Central Metasedimentary Belt. Culotta et al. (1990) proposed that this anomaly delineates the site of a suture, and the Robertson Lake shear zone may represent the surface expression of this pronounced magnetic anomaly.

No age information on the timing of suturing and shearing along the Robertson Lake shear zone is currently available. Based on the occurrence of geochemically similar K-rich plutons belonging to an ultrapotassic to shoshonitic suite that intruded the northern segment of the Frontenac domain as well as the Sharbot Lake and the Elzevir domain at 1090 to $1076 \mathrm{Ma}$ (Marcantonio et al. 1990; Corriveau 1990; Corriveau et al. 1990), these domains were assembled prior to the intrusion of the K-rich plutons. This interpretation requires that metamorphism in the Elzevir domain did not have a pronounced effect on the Frontenac/Sharbot Lake domain. The thermal influence may have been sufficient to reset the ${ }^{40} \mathrm{Ar} /{ }^{39} \mathrm{Ar}$ system in hornblende but not the U-Pb system in sphene.

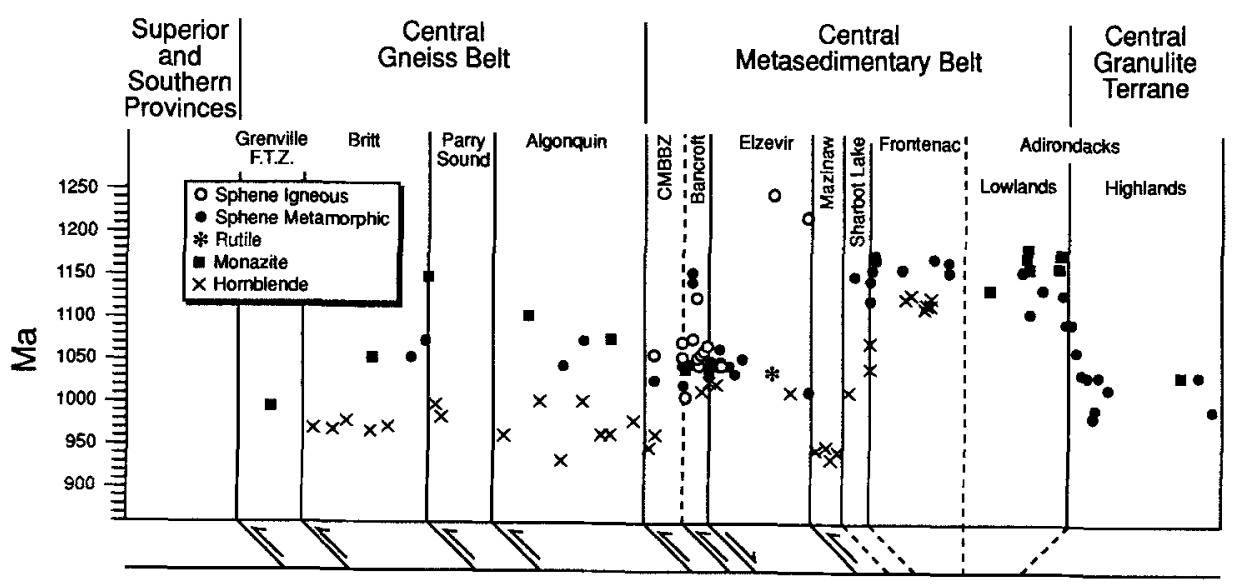

Fig. 3. Distribution of mineral ages, vertical axis, as a function of distance from important shear zones. Horizontal axis represents a cross-section from NW to SE through the Grenville Orogen of Ontario and the adirondacks. The ${ }^{40} \mathrm{Ar} /{ }^{39} \mathrm{Ar}$ hornblende ages from Cosca et al. (1991, 1992) and Culshaw et al. (1991) 
This interpretation is suggested by the similarity of the ${ }^{40} \mathrm{Ar} /{ }^{39} \mathrm{Ar}$ hornblende age obtained by Cosca et al. (1991, 1992) (Fig. 3) for one sample from the Sharbot Lake domain with hornblende ages from the Elzevir domain, and the similarity of the sphene age with sphenes from the Frontenac domain. If this interpretation is correct, the Sharbot Lake/Frontenac and Elzevir domain collided after the high grade metamorphism in the Sharbot Lake/ Frontenac domain (i.e., after ca. $1150 \mathrm{Ma}$ ) and prior to the intrusion of the high-K suite at 1090 to $1076 \mathrm{Ma}$. An alternative explanation is that the two terranes were brought together after about $1020 \mathrm{Ma}$ when the regional metamorphism had ceased in the Elzevir domain. However, the spatial and temporal distribution of the chemically distinct K-rich plutons would then be unsuitable for a reconstruction of the accretionary history of the Central Metasedimentary Belt.

\section{Sharbot Lake shear zone}

The Sharbot Lake shear zone, which separates the Frontenac from the Sharbot Lake domain, may also represent a tectonic discontinuity. The similarity in the sphene ages from both domains indicates that they may have had a common metamorphic history and movement along the fault did not disturb the U-Pb sphene ages. Therefore, the last major displacement along this fault must have occurred immediately after peak metamorphism and prior to the closure of the $\mathrm{U}-\mathrm{Pb}$ system in sphene. Based on the sphene ages, metamorphism of the Sharbot Lake domain is contemporaneous with metamorphism in the Frontenac domain but not the Elzevir domain as previously implied (e.g., Davidson 1986; Corriveau 1990; Corriveau et al. 1990).

\section{Rideau Lake shear zone}

Corriveau (1990) used the distribution of chemically distinct and late $\mathrm{K}$-rich intrusions as evidence that the Elzevir, Sharbot Lake and northern part of the Frontenac domain were already amalgamated at about $1080 \mathrm{Ma}$. She proposed the Rideau Lake shear zone as the major suture that developed after $1076 \mathrm{Ma}$ because no late intrusions of K-rich granitic bodies are found south of this shear zone. This interpretation is different from the model presented here. The sphene data (Fig. 2, Table 1) indicate that the Frontenac domain, as defined in Fig. 2, experienced upper amphibolite facies metamorphism at about 1180 to $1160 \mathrm{Ma}$ and immediately thereafter cooled below the closure temperature for sphene and at 1125 to 1104 Ma below the closure temperature for the ${ }^{40} \mathrm{Ar} /{ }^{39} \mathrm{Ar}$ system in hornblende (Cosca et al. 1991, 1992). If the Rideau Lake shear zone were the site of a suture that developed after $1076 \mathrm{Ma}$, it is fortuitous that rocks with the same post-1180 Ma history and identical metamorphic grade are preserved on either side of the fault. If the Rideau Lake shear zone were ever a suture it developed prior to high grade metamorphism that lasted from ca. 1180 to $1160 \mathrm{Ma}$; any later movement along it was minor.

\section{Tectonic history}

An interpretative and schematic tectonic model outlining the evolution of the southern Grenville Orogen that is consistent with geochronologic and field data is shown in Fig. 4. Metamorphism and magmatic activity at about $1150 \mathrm{Ma}$ are recorded from all domains of the Grenville Orogen in Ontario and the Adirondacks except for the Elzevir and Britt domain. Thrusting of the Parry Sound over the Britt domain at ca. 1160 to $1120 \mathrm{Ma}$ is recorded in zircons from syn-deformational pegmatites (van Breemen et al. 1986) and garnets from within the shear zone (Tuccillo et al. 1992). This relationship indicates that the Britt and Parry Sound domains were attached at this time.

At ca. $1098 \mathrm{Ma}$ the Adirondack Highlands and Lowlands may have rifted apart as indicated by sphenes within a shear zone along the eastern margin of the Lowlands (Mezger et al. 1992). At the same time magmatism occurred in the Highlands (McLelland and Chiarenzelli 1989). At around $1080 \mathrm{Ma}, \mathrm{K}$-rich plutons intruded the

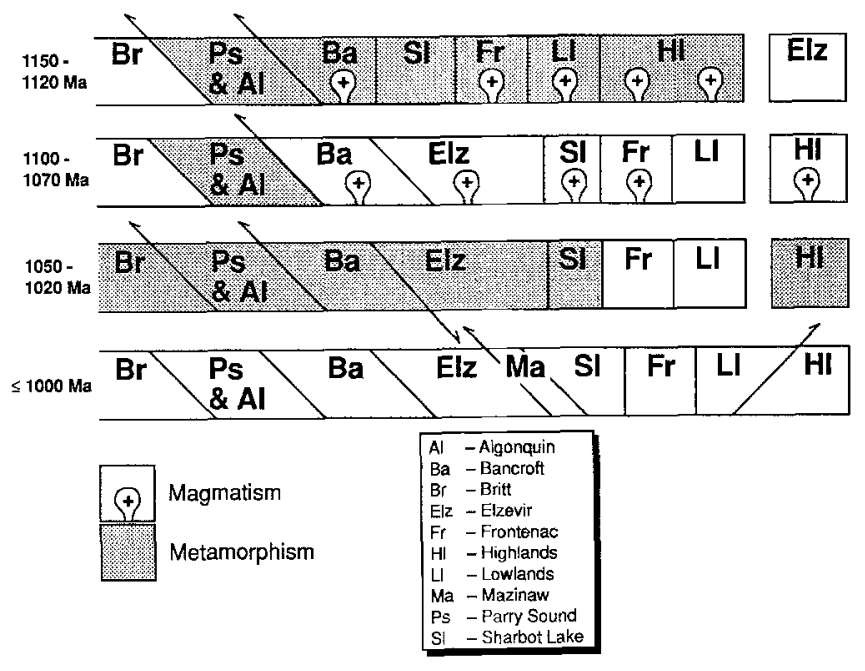

Fig. 4. Tectonic model for the evolution of the southern part of the Grenville Orogen: $1150-1120 \mathrm{Ma}$ A major tectonothermal episode that occurred at about $1150 \mathrm{Ma}$ is recorded in all domains except the Britt and Elzevir domains. The location of the Elzevir domain with respect to the other domains at $1150 \mathrm{Ma}$ is not known. $1100-1070$ Ma This interval is characterized by widespread magmatism in Adirondack Highlands, Bancroft, Elzevir, Sharbot Lake and northern Frontenac domains. The Parry Sound and Algonquin domains experienced regional metamorphism in this interval. No thermal activity is recorded from the Adirondack Lowlands and the Britt domain. It is very likely that the Elzevir had moved into its current position with respect to the Bancroft domain by this time. 1050-1020 $M a$ At 1050 Ma major thrusting and extension occurred in the Central Gneiss Belt and the northern Central Metasedimentary Beit, and granulite facies metamorphism is recorded in the Adirondack Highlands. The metamorphic conditions recorded by a variety of geothermometers and geobarometers correspond to this time interval in the Adirondack Highlands, Elzevir, Bancroft and Britt domains. $\leq 1000 \mathrm{Ma} \mathrm{At}$ about $1000 \mathrm{Ma}$, or shortly thereafter, all the terranes of the Grenville Orogen were finally assembled. Movement along fault zones (e.g., in the eastern Elzevir domain as indicated by the ${ }^{40} \mathrm{Ar} /{ }^{39} \mathrm{Ar}$ hornblende ages of Cosca et al. $(1991,1992)$ led to the final adjustment of different tectonic blocks. No record of post-1000 Ma thermal disturbance or tectonic activity is yet reported in the Grenville Orogen of Ontario or New York 
Elzevir, Sharbot Lake and Frontenac domains. This relationship may indicate the three terranes were juxtaposed by this time. The U-Pb ages of monazite and sphene indicate that the Algonquin domain underwent metamorphism at this time, supporting the suggestion that the Central Gneiss Belt and the Central Metasedimentary Belt were being amalgamated to a large terrane during this tectonometamorphic episode.

Metamorphism that lasted from 1050 to $1020 \mathrm{Ma}$ is recorded in mineral ages from the Britt domain in the NW to the Elzevir domain in the SE as well as the Adirondack Highlands. The Frontenac domain and the Lowlands do not show any evidence of this metamorphic episode, supporting a model that indicates a separation of the Central Metasedimentary Belt from the Central Granulite Terrane at this time. The sphenes in the Sharbot Lake domain were unaffected but the hornblendes may record this metamorphism. In the Algonquin domain this metamorphism at ca. $1050 \mathrm{Ma}$ is recorded in the U-Pb ages of sphenes and zircons overgrowing baddeleyite in coronitic gabbros (Davidson and van Breemen 1988), but this metamorphism did not reach high enough temperatures to reset monazite. During this tectonometamorphic episode thrusting was reinitiated along the Parry Sound shear zone as well as the Central Metasedimentary Belt Boundary Zone (McEachern et al. 1990). At the same time an extensional shear zone developed in the southern Bancroft and northwestern Elzevir domains (Mezger et al. 1991b) due to overthickening of continental crust.

At around $1000 \mathrm{Ma}$, the last major thermal activity occurred along the Grenville Front. It is also likely that at about this time the Adirondack Highlands and Lowlands were welded together. A late NE-SW oriented fault developed in the eastern Elzevir domain which led to the uplift of a block adjacent to the Sharbot Lake domain. The different cooling history of this block is recorded in ${ }^{40} \mathrm{Ar} /{ }^{39} \mathrm{Ar}$ ages obtained on hornblendes (Cosca et al. 1991, 1992). These ages are ca. $100 \mathrm{Ma}$ younger than ${ }^{40} \mathrm{Ar} /{ }^{39} \mathrm{Ar}$ hornblende ages obtained from the western Elzevir domain. This tectonic model is certainly tentative, but it can be tested by dating the movement along the major shear zones.

\section{Cooling and uplift history}

The U-Pb ages reported in this paper can be combined with the ${ }^{40} \mathrm{Ar} /{ }^{39} \mathrm{Ar}$ ages (Cosca et al. 1991, 1992) and the metamorphic temperatures (Anovitz and Essene 1990) obtained for the Grenville Orogen as well as the closure temperatures for the different parent-daughter systems in each mineral to obtain cooling rates on a regional scale. This yields uniform time-integrated cooling rates of 1 to $4^{\circ} \mathrm{C} / \mathrm{Ma}$ for all the domains for the first $200 \mathrm{Ma}$ following the last regional metamorphism. Assuming a geothermal gradient of $25^{\circ} \mathrm{C} / \mathrm{km}$ and that uplift was due to erosion the time-integrated uplift rates for all parts of the Grenville Orogen were about $120 \pm 40 \mathrm{~m} / \mathrm{Ma}$. However, uplift rates during and immediately after peak orogenic activity may have been significantly faster (Mezger et al. 1991b). Within the vicinity of the Bancroft shear zone the rates were about $16{ }^{\circ} \mathrm{C} / \mathrm{Ma}$ for a short time interval immedi- ately after peak metamorphism due to the development of an extensional shear zone. Elsewhere, the similarity of $\mathbf{U}$ $\mathrm{Pb}$ zicron ages (e.g., Marcantonio et al. 1990; van Breemen and Davidson 1990) with the U-Pb sphene ages presented in this study and the peak metamorphic temperatures of ca. $700{ }^{\circ} \mathrm{C}$ in the Frontenac domain indicate that initial cooling rates may have been as high as $10^{\circ} \mathrm{C} / \mathrm{Ma}$. At about $30 \mathrm{Ma}$ after peak metamorphism they reached the commonly observed rate of 1 to $4^{\circ} \mathrm{C} / \mathrm{Ma}$ as indicated by the ${ }^{40} \mathrm{Ar} /{ }^{39} \mathrm{Ar}$ mineral ages (Cosca et al. 1991, 1992).

The currently exposed level of the Grenville Orogen is very similar to that exposed during Eo-Cambrian to Silurian times as indicated by onlap of flatlying sediments of late Proterozoic to early Paleozoic age onto Grenvillian basement rocks. Assuming that uplift was continuous from the end of the Grenville orogenic cycle to about 600 to $700 \mathrm{Ma}$ when the oldest red-bed sediments were deposited on the Grenville basement rocks (Isachsen and Fisher 1970), this yields an average erosion rate of $100 \mathrm{~m} / \mathrm{Ma}$ for the deepest parts of the Central Gneiss Belt and $30 \mathrm{~m} / \mathrm{Ma}$ for the shallowest parts in the Central Metasedimentary Belt. Similar time-integrated denudation rates and cooling rates have been reported from the Adirondacks (Mezger et al. 1991a), Archean Pikwitonei granulite domain (Mezger et al. 1990), Lewisian granulites (Humphries and Cliff 1982) and from model calculations (Pitman and Golovchencko 1991). Increasingly this consistency of long-term uplift rates suggest a pattern that is typical for the exhumation of deep parts of large orogenic belts.

\section{Conclusions}

The Central Metasedimentary Belt and the Central Gneiss Belt exhibit distinct tectonic styles. Major thrusts and nappes are typical for the Central Gneiss Belt but have not been mapped in the Central Metasedimentary Belt (Davidson 1984a, b, 1986). Mineral assemblages in the currently exposed metamorphic rocks within the Central Metasedimentary Belt yield average equilibration pressure of 4 to $6 \mathrm{kbar}$ which correspond to paleodepths of 15 to $22 \mathrm{~km}$ assuming an average density of $2.7 \mathrm{~g} / \mathrm{cm}^{3}$. In contrast, the pressures in the Central Gneiss Belt reached at least $10 \mathrm{kbar}$ (Anovitz and Essene 1990). Since the current crustal thickness throughout the Grenville Orogen is uniformly about 35 to $40 \mathrm{~km}$ (Mereu et al. 1986) these differences in the estimated pressures may provide an indication of the variation of the crustal thickness during peak metamorphism. The difference in crustal thickness between the Central Gneiss Belt and Central Metasedimentary Belt is consistent with the differences in their tectonic style. When compared with younger well studied and better known orogenic belts the Central Gneiss Belt shows many similarities to the Himalayan Orogen (e.g., Allègre et al. 1984). In both orogens crustal thicknesses up to $75 \mathrm{~km}$ were obtained by crustal shortening and stacking of nappes of different origin.

In contrast to the Central Gneiss Belt, the history and tectonic evolution of the Central Metasedimentary Belt and Central Granulite Terrane show great similarity with that of western North America (e.g., Coney et al. 1980; 
Saleeby 1983) where crustal blocks with distinct histories were accreted laterally. Subsequent to accretion these crustal blocks may have been thrust on top of each other. However, there is no evidence for extensive thrusting after accretion in the Central Metasedimentary Belt. This observation is also consistent with the lower pressures attained by the currently exposed rocks. In the Grenville Orogen the time of accretion of the different terranes can not be determined with great accuracy due to the lack of suitable minerals in the shear zones that separate the terranes. However, thermochronology can be used to delineate the histories and regional extent of different suspect terranes and constrain their tectonic histories.

The comparison of the geologic history of the Grenville Orogen with more recent orogenic belts reveals striking similarities between ancient and modern orogens. Evidence for both of the major tectonic processes that are important in modern orogens such as lateral accretion and extensive crustal thickening can be observed in the Grenville Orogen. Based on the data and observations presented here it is evident that processes that led to the formation of the Grenville Orogen during Mid-Proterozoic times may have been quite similar to those operating in currently active orogenic belts (e.g., Windley 1986).

\section{Appendix}

Sample locations (UTM coordinates)

\begin{tabular}{lll}
\hline Sample & Northing & Easting \\
\hline Monazite & & \\
ALG85-1 & 50426 & 7145 \\
BUR44 & 51470 & 5185 \\
REN82a-28 & 50495 & 3310 \\
SSA12 & 50510 & 6950 \\
Rutile & & \\
$90-06$ & & \\
Spene & 49425 & 2710 \\
2927 & & \\
$89-03$ & & \\
$89-04$ & Renfrew County & \\
$89-05$ & 49575 & 2930 \\
$89-06$ & 49830 & 2830 \\
$89-08$ & 49940 & 2760 \\
$89-13$ & 50085 & 2808 \\
$89-17$ & 50180 & 2930 \\
$89-18$ & 50190 & 3090 \\
$89-20$ & 50363 & 3386 \\
$89-22$ & 50285 & 3420 \\
$89-23$ & 49675 & 4090 \\
$90-08$ & 49325 & 4045 \\
$90-17$ & 49170 & 4030 \\
$90-31$ & 50000 & 3670 \\
$90-38$ & 50110 & 3720 \\
$90-39$ & 49885 & 7190 \\
$90-40$ & 49900 & 7000 \\
$90-41$ & 49825 & 6870 \\
$90-45$ & 49660 & 6760 \\
$90-45 s$ & 49563 & 6730 \\
$90-46$ & 49730 & 7060 \\
$90-47$ & 49730 & 7060 \\
& 49660 & 7108
\end{tabular}

\begin{tabular}{lll}
\hline Sample & Northing & Easting \\
\hline $90-48$ & 49450 & 7075 \\
$90-71 \mathrm{a}$ & 49280 & 4145 \\
$90-77$ & 49265 & 3825 \\
$90-78 \mathrm{~b}$ & 49230 & 3675 \\
$90-79$ & 49270 & 3665 \\
$90-82 \mathrm{a}$ & 49465 & 3650 \\
$90-82 \mathrm{~b}$ & 49465 & 3650 \\
$90-83$ & 49605 & 3650 \\
$90-88$ & 49990 & 6755 \\
$90-88 \mathrm{~b}$ & 49990 & 6755 \\
ACP/3 & 50205 & 3148 \\
BA-28 & 49915 & 2710 \\
CHF2 & 50310 & 6380 \\
Diane & 50197 & 2957 \\
GO-4B & 49730 & 7060 \\
GO-5D & 49730 & 7060 \\
RDT3 & 50125 & 6610 \\
XX & 49830 & 7135 \\
ZR.15 & Near Quadeville \\
\hline
\end{tabular}

Acknowledgments. This study was supported by NSF grants EAR 82-12764, 88-05083, 89-03805, 90-04302, 90-04413. A. Davidson and R.M. Easton are thanked for generously sharing their insights into Grenville geology and for their help in the field. L.M. Anovitz, M.A. Cosca and D. Nielsen are thanked for providing some of the samples used in this study. Detailed Reviews by S. Daly, L. Heaman and an anonymous reviewer led to improvements in the paper and are very much appreciated.

\section{References}

Allègre CJ et al. (1984) Structure and evolution of the HimalayaTibet orogenic beit. Nature 307:17-22

Anovitz LM, Essene EJ (1990) Thermobarometry and pressuretemperature paths in the Grenville Province of Ontario, J Petrol $31: 197-241$

Baldwin SL, Harrison TM, FitzGerald JD (1990) Diffusion of ${ }^{40} \mathrm{Ar}$ in metamorphic hornblende. Contrib Mineral Petrol $105: 691-703$

Bartholomew MJ, Force ER, Krishna Sinha A, Herz N (1984) The Grenville Event in the Appalachians and related topics. Geol Soc Am Spec Pap 194

Bohlen SR, Valley JW, Essene EJ (1986) Metamorphism in the Adirondacks I: petrology, pressure and temperature. $J$ Petrol 26:971-992

Cameron AE, Smith DH, Walker RL (1967) Mass spectometry of nanogram-size samples of lead. Anal Chem 41:525-526

Christensen JN, Rosenfeld JL, DePaolo DJ (1989) Rates of tectonometamorphic processes from rubidium and strontium isotopes in garnet. Science $244: 1465-1469$

Committee for the Magnetic Anomaly Map of North America, compilers (1987) Magnetic Anomaly Map of North America, Continental-scale map, Boulder, Colorado, Geol Soc Am.

Coney PJ, Jones DL, Monger JWH (1980) Cordilleran suspect terranes. Nature 288:328-333

Connelly JN (1985) The Elzevir batholith: emplacement history with respect to the Grenville Supergroup and Flinton Group, southeastern Ontario. In: Current research, part B. Geol Surv Can Pap 85-1B: 161-167

Copeland P, Parrish RR, Harrison TM (1988) Identification of inherited radiogenic $\mathrm{Pb}$ in monazite and its implication for the U-Pb system. Nature 333: 700-763 
Corriveau L (1990) Proterozoic subduction and terrane amalgamation in the southwestern Grenville Province, Canada: evidence from ultrapotassic to shoshonitic plutonism Geology $18: 614-617$

Corriveau L, Heaman LM, Marcantonio F, van Breemen O (1990) 1.1 Ga K-rich alkaline plutonism in the SW Grenville Province. Contrib Mineral Petrol 105:473-485

Cosca MA, Sutter JF, Essene EJ (1991) Late metamorphic cooling and inferred uplift/erosion history of the Ontario Grenville Province: constraints from ${ }^{40} \mathrm{Ar} /{ }^{39} \mathrm{Ar}$ thermochronology. Tectonics 10:959-977

Cosca MA, Essene EJ, Kunk MJ, Sutter JF (1992) Differential unroofing within the Central Metasedimentary Belt of the Grenville Orogen: constraints from ${ }^{40} \mathrm{Ar} /{ }^{39} \mathrm{Ar}$ thermochronology. Contrib Mineral Petrol 110:211-225

Culotta RC, Pratt T, Oliver J (1990) A tale of two sutures: COCORP's deep seismic surveys of the Grenville Province in the eastern US midcontinent. Geology 18:646-649

Culshaw NG, Corrigan D, Drage J, Wallace P (1988) Georgian Bay geological synthesis: Key Harbour to Dillon, Grenville Province of Ontario. Geol Surv Can Spec Pap 88-1C:129-133

Culshaw N, Reynolds PH, Check G (1991) A ${ }^{40} \mathrm{Ar} /{ }^{39} \mathrm{Ar}$ study of post-tectonic cooling in the Britt domain of the Grenville Province, Ontario. Earth Planet Sci Lett 105:405-415

Davidson A (1984a) Identification of ductile shear zones in the southwestern Grenville Province of the Canadian Shield. In Kröner A, Greiling R (eds) Precambrian tectonics illustrated Schweizerbart, Stuttgart, pp. 263-279

Davidson A (1984b) Tectonic boundaries within the Grenville Province of the Canadian Shield. J Geodynamics 1:433-444

Davidson A (1986) New interpretations in the southwestern Grenville Province. In: Moore JM, Davidson A, Baer AJ (eds) The Grenville Province. Geol Assoc Can Spec Pap 31, pp 61-74

Davidson A, van Breemen O (1988) Baddeleyite-zircon relationships in coronitic metagabbro, Grenville Province, Ontario: implications for geochronology. Contrib Mineral Petrol 100:291-299

Davis DW, Bartlett JR (1988) Geochronology of the Belmont Lake metavolcanic complex and implications for crustal development in the Central Metasedimentary Belt, Grenville Province, Ontario. Can J Earth Sci 25:1751-1759

Davis DW, Pezzutto F, Ojakangas RW (1990) The age and provenance of metasedimentary rocks in the Quetico Subprovince, Ontario, from single zircon analyses: implications for Archean sedimentation and tectonics in the Superior Province. Earth Planet Sci Lett 97:54-64

Dickin AP, McNutt RH (1989) Nd model age mapping of the southeast margin of the Archean foreland in the Grenville Province of Ontario, Geology 17:299-302

Dickin AP, McNutt RH, Clifford PM (1990) A neodymium isotope study of plutons near the Grenville Front in Ontario, Canada. Chem Geol 83:315-324

Easton RM (1986) Geochronology of the Grenville Province, part I: compilation of data; part II: synthesis and interpretation. In: Moore JM, Davidson A, Baer AJ (eds) The Grenville Province. Geol Assoc Can Spec Pap 31, pp 127-174

Easton RM (1992) Revised terrane subdivision and observations on the tectonic assembly of the Central Metasedimentary Belt (CMB), Ontario (abstract). Workshop Friends of the Grenville

Easton RM, Ford F (1991) Geology of the Mazinaw Area. Ont Geol Surv Misc Pap 157:95-106

Gariépy C, Verner D, Doig R (1990) Dating Archean metamorphic minerals southeast of the Grenville front, western Quebec, using $\mathrm{Pb}$ isotopes. Geology 18: 1078 1081

Gascoyne M (1986) Evidence for the stability of potential nuclear waste host, sphene, over geological time, from uranium-lead ages and uranium series disequilibrium measurements. Appl Geochem $1: 199-210$

Geraghty EP, Isachsen YW, Wright SF (1981) Extent and character of the Carthage-Colton mylonite zone, Northwest Adirondacks, New York. Nucl Regulatory Comm, NUREG/CR-1865

Hammer S (1988) Ductile thrusting at mid-crustal level, southwestern Grenville Province. Can J Earth Sci 25:1049-1059
Hanson GN, Catanzaro EJ, Anderson DH (1971) U-Pb ages for sphene in a contact metamorphic zone. Earth Planet Sci Lett $12: 231-237$

Harrison TM (1981) Diffusion ${ }^{40} \mathrm{Ar}$ in hornblende. Contrib Mineral Petrol 78:324-331.

Hatcher RD Jr (1989) Tectonic synthesis of the US Appalachians. In: Hatcher RD Jr, Thomas WA, Viele GW (eds) The AppalachianOuachita orogen in the United States. Geol Soc Am F2, pp 511-535

Heaman L, Parrish R (1991) U-Pb geochronology of accessory minerals. In: Heaman L, Ludden JN (eds) Applications of radiogenic isotope systems to problems in geology (Short course handbook 19) Mineral Assoc Canada, pp 59-102

Heaman LM, McNutt RH, Krogh TE (1986) Geological significance of $\mathrm{U}-\mathrm{Pb}$ and $\mathrm{Rb}-\mathrm{Sr}$ ages for two pre-tectonic granites from the Central Metasedimentary Belt, Ontario. In: Moore JM, Davidson A, Baer AJ (eds) The Grenville Province. Geol Assoc Can Spec Pap 31, pp 209-221

Hoffman PF (1991) Did the breakup of Laurentia turn Gondwana inside out? Science 252:1409-1412

Hoffman PF, Bowring SA (1984) A shortlived 1.9 Ga continental margin and its destruction, Wopmay Orogen, Northwest Canada. Geology 12:68-72

Humphries FJ, Cliff RA (1982) Sm-Nd dating and cooling history of Scourian granulites, Sutherland, NW Scotland. Nature $295: 515-517$

Isachsen YW, Fisher DW (1970) Geologic map of New York State. NY State Mus Map Chart Ser 16

Krogh TE (1982) Improved accuracy of U-Pb zircon ages by creation of more concordant systems using an air-abrasion technique. Geochim Cosmochim Acta 46:637-649

Krogstad EJ, Balakrishnan S, Mukhopadhyay DK, Rajamani V, Hanson GN (1989) Plate tectonics 2.5 Ga ago: evidence at Kolar, South India. Science $243: 1337-1340$

Laubscher H, Bernoulli D (1982) History and deformation of the Alps. In: Hsü KY (ed) Mountain building processes. Academic Press, London, 169-180

Ludwig KR (1980) Calculation of uncertainties of U-Pb isotope data. Earth Planet Sci Lett 46:212-220

Ludwig KR (1982) A computer program to convert raw U-Th-Pb isotope ratios to blank-corrected isotope ratios and concentrations with associated error-corrleations. US Geol Surv OpenFile Rep $82-820$

Lumbers SB, Heaman LM, Vertolli VM, Wu T-W (1990) Nature and timing of Middle Proterozoic magmatism in the Central Metasedimentary Belt, Grenville Province, Ontario. In: Gower CF, Rivers T, Ryan AB (eds) Mid-Proterozoic Laurentia-Baltica. Geol Assoc Can Spec Pap 38, pp. 243-276

Lumbers SB, Wu T-W, Heaman LM, Vertolli VM (1991) Petrology and age of the A-type Mulock granite batholit, northern Grenville Province, Ontario. Precambrian Res 53:199-231

Manhès G, Allègre CJ, Provost A (1984) U-Th-Pb systematics of the eucrite "Juvinas": precise age determination and evidence for exotic lead. Geochim Cosmochim Acta 48:2247--2264

Marcantonio F, McNutt RH, Dickin AP, Heaman LM (1990) Isotopic evidence for the crustal evolution of the Frontenac Arch in the Grenville Province of Ontario, Canada. Chem Geol $83: 297-314$

Mattinson JM (1978) Age, origin, and thermal history of some plutonic rocks from the Salinian Block of California. Contrib Mineral Petrol 67:233-245

Mattison JM (1986) Geochronology of high pressure-low temperature Franciscan metabasites. A new approach using the U$\mathrm{Pb}$ system. Geol Soc Am Mem 164:95-105

McEachern SJ, Hanmer S, van Breemen O (1990) Structure and geochronology of the Central Metasedimentary Belt boundary thrust zone, Pembroke, Ontario (abstract). Geol Soc Am Abstr Program 22:54

McLelland JM, Chiarenzelli J (1989) Age of xenolith-bearing olivine metagabbro, eastern Adirondack Mountains, New York. J Geol $97: 373-376$

McLelland JM, Chiarenzelli J (1990) Geochronologic studies in the 
Adirondack Mountains and the implications of a middle Proterozoic tonalite suite. In: Gower CF, Rivers $\mathrm{T}$, Ryan $\mathrm{AB}$ (eds) Mid-Proterozoic Laurentia-Baltics. Geol Assoc Can Spec Pap 38, pp 175-194

McLelland JM, Chiarenzelli J, Whitney P, Isachsen Y (1988) U-Pb zircon geochronology of the Adirondack Mountains and implications for their tectonic evolution. Geology 16:920-924

Mereu RF, Wang D, Kuhn O, Forsyth DA (1986) Summary of the results of the 1982 COCRUST long-range seismic experiment across the Ottawa-Bonnechere Graben and western Grenville Front. In: Moore JM, Davidson A, Baer AJ (eds) The Grenville Province. Geol Assoc Can Spec Pap 31, pp 235-240

Mezger K (1990) Geochronology in granulites. In: Vielzeuf D, Vidal PH (eds) Granulites and crustal evolution. NATO Adv Study Inst, Kluwer Acad Publ, Dordrecht, pp 451-470

Mezger K, Hanson GN, Bohlen SR (1989a) U-Pb systematics of garnet: dating the growth of garnet in the late Archean Pikwitonei granulite domain at Cauchon and Natawahunan Lakes, Manitoba, Canada. Contrib Mineral Petrol 101:136-148

Mezger K, Hanson GN, Bohlen SR (1989b) U-Pb ages of metamorphic rutiles: application to the cooling history of high grade terranes. Earth Planet Sci Lett 96:106-118

Mezger K, Bohlen SR, Hanson GN (1990) Metamorphic history of the Archean Pikwitonei granulite domain and the Cross Lake subprovince, Superior Province, Manitoba, Canada. J Petrol $31: 483-517$

Mezger K, Rawnsley CM, Bohlen SR, Hanson GN (1991a) U-Pb garnet, sphene, monazite, and rutile ages: implications for the duration of high-grade metamorphism and cooling histories, Adirondack Mts, New York. J Geol 99: 415-428

Mezger K, van der Pluijm BA, Essene EJ, Halliday AN (1991b) Synorogenic collapse: a perspective from the middle crust, the Proterzoic Grenville Orogen. Science 254:695-698

Mezger K, van der Pluijm BA, Essene EJ, Halliday AN (1992) The Carthage-Colton mylonite zone (Adirondack Mts) the site of a cryptic suture? J Geol 100:630-638

Moecher DP, Essene EJ, Anovitz LM (1988) Calculation and application of clinopyroxene-garnet-plagioclase-quartz geobarometers. Contrib Mineral Petrol 100:92-106

Moores EM (1991) Southwest US-East Antarctica (SWEAT) connection: a hypothesis. Geology 19:425-428

Ontario Geological Survey (1991) Bedrock geology of Ontario, Southern sheet. Ont Geol Surv, Map 2544 scale 1:1,000,000

Parrish RR (1991) U-Pb dating of monazite and its application to geological problems. Can J Earth Sci $27: 1435-1450$

Patchett PJ, Ruiz J (1987) Nd isotopic ages of crust formation and metamorphism in the Precambrian of eastern and southern Mexico. Contrib Mineral Petrol 96:523-528

Pitman WC, Golovchencko X (1991) The effect of sea level changes on the morphology of mountain belts. J Geophys Res 96:6879-6891

Priem HNA, Kronenber SB, Boelrijk NAIM, Hebeda EH (1989) $\mathrm{Rb}-\mathrm{Sr}$ and $\mathrm{K}$-Ar evidence for the presence of a $1.6 \mathrm{Ga}$ basement underlying the 1.2 Ga Garzon-Santa Marta granulite belt in the Columbian Andes. Precambrian Res 42:315-324

Saleeby JB (1983) Accretionary tectonics of the North American Cordillera. Annu Rev Earth Planet Sci 15:45-73

Sengör AMC (1991) Plate tectonics and the orogenic research after 25 years: synopsis of a Tethyan perspective. Tectonophysics $187: 315-344$

Steiger RH, Jäger E (1977) Subcommission on geochronology. Convention on the use of decay constants in geo- and cosmochronology. Earth Planet Sci Lett $36: 359-362$

Stockwell CH (1964) Fourth report on structural provinces, orogenies, and time-classification of rocks of the Canadian Precambrian Shield. In: Age determinations and geological studies, part II: geological studies. Geol Surv Can Pap 64-17:1-21

Tilton GR (1973) Isotopic lead ages of chondritic meteorites. Earth Planet Sci Lett 19:321-329

Tuccillo ME, Mezger K, Essene EJ, van der Pluijm BA (1992) Thermobarometry, geochronology, and the interpretation of $P-T$ - $t$ data in the Britt Domain, Ontario Grenville Province, Canada. J Petrol 33: 1225-1259

van Breemen O, Davidson A (1988) U-Pb zircon ages of granites and syenites in the Central Metasedimentary Belt, Grenville Province, Ontario. In: Radiogenic age and isotopic studies: rep 2. Geol Surv Can Pap 88-2:45-50

van Breemen O, Davidson A (1990) U-Pb zircon and baddeleyite ages from the Central Gneiss Belt, Ontario. Geol Surv Can Pap $89-2: 85-92$

van Breemen O, Hanmer SK (1986) Zircon morphology and the $\mathrm{U} / \mathrm{Pb}$ geochronology in active shear zones: studies on syntectonic intrusions along the northwest boundary of the Central Metasedimentary Belt, Grenville Province, Ontario. Geol Surv Can Pap 86-1B:775-785

van Breemen O, Davidson A, Loveridge WD, Sullivan RW (1986) $\mathrm{U}-\mathrm{Pb}$ zircon geochronology of Grenville tectonites, granulites and igneous precursors, Parry Sound, Ontario. In: Moore JM, Davidson A, Baer AJ (eds) The Grenville Province. Geol Assoc Can Spec Pap 31, pp 191-207

Vance D, O'Nions RK (1990) Isotopic chronometry of zoned garnets: growth kinetics and metamorphic histories. Earth Planet Sci Lett 97:227-240

van der Pluijm BA, Carlson KA (1989) Extension in the Central Metasedimentary Belt of the Ontario Grenville: timing and tectonic significance. Geology 17:161-164

Windley BF (1986) Comparative tectonics of the western Grenville and western Himalaya. In: Moore JM, Davidson A, Baer AJ (eds) The Grenville Province. Geol Assoc Can Spec Pap 31, pp 341-348

Wynne-Edwards HR (1972) The Grenville Province. In: Price RA, Douglas RJW (eds) Variations in tectonic styles in Canada. Geol Assoc Can Spec Publ 11, pp 263-334

Editorial responsibility: J. Patchett 